\title{
The Role of Border Governorates in Redistribution of Population and Labour Force, Egypt, 1976-2015 (A Study in Labour Force and Regional Development)
}

Ezzat Zayyan*

\begin{abstract}
The main objective of the study is to assess the extent of contribution of border governorates to the process of population and labour force distribution. The study also tries to estimate the growth of both population and labor force in border governorates, to measure the contribution of border governorates to the movements of population (internal migration), and to analyze the developments of characteristics of the population and labour force in general, and the workers in particular. These governorates are: The Red Sea, The New Valley, Matrough, North Sinai, and South Sinai.

The five border governorates assume about $79 \%$ of the land area of the country. The total number of population in border governorates amounted to 1669 thousand persons as of mid-2015, i.e. less than $2 \%$ of the total population. The growth rates of population were nearly double those of the total population during most of the study period, except for the last year (2015). The natural increase rate $(2.6 \%)$ is slightly higher than the national level $(2.3 \%)$ in 2015 . They attracted about 247000 persons during the period 1996-2006, representing only 5.2\% of those who internally migrated at the national level. The major cause of population movement to border governorates was (looking for work) (43\%), followed by (attendance) (42\%), where the latter are the followers of the earlier. The urbanization level (68\%) was seemingly higher than that of the national level (43\%) as of 2006.

The total number of labour force in border governorates amounted to 592 thousand in 2015 , i.e. about $2 \%$ of total labour force. The growth rates of such labour force are more than double those of the country level, during most of the study period, while they became even lower than the country level in 2015, as is the case with population. Refined activity rate was $65 \%$, similar to that of the national level in 2006, but was increasing rapidly in border governorates. Unemployment rates during the period 1986-2006 (7\%) were lower than those of the national level (about 11\%). The border governorates are no longer able to attract more population and provide job opportunities. More than half the unemployed had secondary and higher education (57\% in 2006 and 56\% in 2015). The relative share of unemployed with university education and above increased rapidly from $21 \%$ in 2006 to $32 \%$ in 2015 at the national level, and even faster from $14 \%$ to $32 \%$ in border governorates.
\end{abstract}

* Assistant Professor, Regional Development Center, Institute of National Planning, Egypt. 
The levels, patterns, and trends of educational status of the labour force are more or less similar to those of the national level. Female labour force is better educated than the male counterpart, at all levels. Employment status of the workers is dominated by "wage workers", at all levels. The "private sector" continued to be the major job provider, with a rapidly increasing trend at all levels. As for female workers, the "government" became the major job provider in border governorates. Workers with "the white collar occupations" (scientific, professional, technical, administrative, and managerial workers) assumed the first rank, with an increasing trend. The "community services sector" was the dominant one, with an increasing trend. The relative share of "agriculture" was lower and rapidly decreasing in border governorates, from $26 \%$ in 1996 to $15 \%$ in 2006.

The study recommends to adopt objective criteria to establish and cancel governorates. It is suggested to divide border governorates to be allocated to neighboring governorates. Any new universities are not to be established in the old Valley and Delta. Establishing new universities and faculties, especially those with theoretical specializations, in the established remote border communities. Executing development plans prepared for the current border governorates. Establishing any new regions (regardless of their number and nature) has to include complete governorates. Great interest has to be paid to establish new communities on cultivable lands in current border governorates. [Bul. Soc. Géog. d'Égypte, 2017, 90: 21-57]

\section{Objectives of the Study:}

The main objective of the study is to assess the extent of contribution of border governorates to the process of population distribution strategies, policies, and programs during the last few decades. In particular, the study tries to achieve the following objectives:

- To estimate the growth of both population and labor force in border governorates,

- To measure the contribution of border governorates to the movements of population (internal migration), and

- To analyze the developments of characteristics of the population and labour force in general, and the workers in particular.

\section{Data Sources:}

Although the study covers the time period 1976-2015, it depends mainly on the population censuses that cover the time period (1976-2006). In addition, the most recent data published by Central Agency of Public Mobilization and Statistics (CAPMAS) in 2016 is used for some characteristics of the population and labour force. As for comparability of data, between censuses and estimates of 2015 , it is noteworthy that such estimates are carried out by the same official agency executing the censuses, i.e. the Central Agency for Public Mobilization and Statistics (CAPMAS). Accordingly, the researcher takes the estimates of 2015 for granted, just to utilize the last available data for some variables. 


\section{Methodology:}

The analytical tabular descriptive analysis is adopted to achieve the objectives of the study, as for assessing the relative weight of border governorates as for their shares of both population and labour force. In addition, the cartographic techniques are used to indicate the geographical distribution and different characteristics of both population and labour force levels, patterns and trends.

\section{Organization:}

The study consists of four sections in addition to the introduction. As usual, the introduction indicates the objectives, the data sources, and the methodology. Section two contains the analysis of levels, patterns, and trends of population. Section three deals with levels, patterns and trends of the labour force. Section four presents the developments in the characteristics of the workers as for the employment status, occupations, the economic activities, and the institutional structure. Finally, the concluding section presents the conclusions and recommendations of the study.

\section{1) Levels, Patterns and Trends of Population in Border Governorates:}

Before proceeding to the analysis of levels, patterns and trends of the population and labour force in border governorates, it is worthy to present the absolute, uninhabited, inhabited, cultivated and cultivable areas in such governorates. This is to be carried out to assess the relative share of border governorates as for the land area, the population, and the labour force. In turn, this indicates the administrative burden endured by the administrative apparatus in such governorates, compared to other non-border governorates (Abdel-Hakim, 1998, 3-5; Abdel-Hamid, 1994, 5-15; El-Bakly, 2016, 1; ElZamly, 2016, 201-207; INP. 2003, 127-130).

Table 1. Absolute and Relative Size of Total, Inhabited, and Uninhabited Land Areas and Population of Border Governorates, Egypt, 2015.

\begin{tabular}{|l|c|c|c|c|c|c|c|c|c|c|}
\hline \multirow{2}{*}{ Governorate } & \multicolumn{2}{|c|}{$\begin{array}{c}\text { Inhabited } \\
\text { Areas }\end{array}$} & \multicolumn{2}{c|}{$\begin{array}{c}\text { Uninhabited } \\
\text { Areas }\end{array}$} & \multicolumn{2}{c|}{$\begin{array}{c}\text { Total Land } \\
\text { Areas }\end{array}$} & \multicolumn{2}{c|}{$\begin{array}{c}\text { Agricultura } \\
\text { I Areas }\end{array}$} & \multicolumn{2}{c|}{$\begin{array}{c}\text { Cultivable } \\
\text { Areas }\end{array}$} \\
\cline { 2 - 13 } & $\mathbf{k m}^{2}$ & $\mathbf{\%}$ & $\mathbf{k m}^{2}$ & $\mathbf{\%}$ & $\mathbf{k m}^{\mathbf{2}}$ & $\mathbf{\%}$ & $\mathbf{k m}^{2}$ & $\mathbf{\%}$ & $\mathbf{k m}^{\mathbf{2}}$ & $\mathbf{\%}$ \\
\hline The Red Sea & 71 & 0.1 & 129929 & 14 & 130000 & 13 & 0.0 & 0 & 0 & 0 \\
\hline $\begin{array}{l}\text { The New } \\
\text { Valley }\end{array}$ & 1112 & 2 & 375393 & 41 & 376505 & 38 & 342 & 1 & 0 & 0 \\
\hline Matrouh & 4020 & 6 & 208092 & 23 & 212112 & 22 & 1208 & 4 & 1164 & 25 \\
\hline North Sinai & 184 & 3 & 27380 & 3 & 27564 & 3 & 33 & 0 & 55 & 1 \\
\hline South Sinai & 11822 & 18 & 16616 & 2 & 28438 & 3 & 5683 & 17 & 0 & 0 \\
\hline $\begin{array}{l}\text { Total Border } \\
\text { Governorates }\end{array}$ & 17209 & 27 & 757410 & 83 & 774619 & 79 & 7266 & 21 & 1219 & 26 \\
\hline Total Egypt & $\mathbf{6 4 6 6 1}$ & $\mathbf{1 0 0}$ & $\mathbf{9 1 7 0 8 6}$ & $\mathbf{1 0 0}$ & $\mathbf{9 8 1 7 4 7}$ & $\mathbf{1 0 0}$ & $\mathbf{3 4 2 1 5}$ & $\mathbf{1 0 0}$ & $\mathbf{4 6 0 4}$ & $\mathbf{1 0 0}$ \\
\hline
\end{tabular}

Sources:

- INP (2003) "Dividing Egypt Into Planning Regions", Cairo: INP. (Planning and Development Issues Series, No. 162), pp. 128-130.

- INP (2008) "Population Characteristics and Their Reflection on Social Values", Cairo: INP. (Planning and Development Issues Series, No. 210), p. 73. 
As indicated in Table (1), the five border governorates together assume about $79 \%$ of the total land area of the country. Accordingly, about 20 governorates assume only $21 \%$ of the total country land area. Regardless of the population distribution to be dealt with later, these figures indicate the great imbalance as for the absolute and relative land areas of the border governorates. As a result, the administrative structure of the Egyptian governorates can be simply considered as highly distorted. Administratively, this means that five Governors, with their deputies, and general secretaries, and under-secretaries are responsible for the administration of about fourfifths of the country land area. By contrast, more than 20 Governors are responsible for only about one-fifth of the country area. This may be considered as another aspect of imbalance, as for the authorities and responsibilities of the administrative apparatus in the country. It is left to the following section to assess the role of such governorates in absorbing population increase on the one hand, and providing new job opportunities on the other (INP, 2003, pp. 128-130; INP, 2008, p. 73).

Within border governorates, the relative share of inhabited areas is very low $(2.2 \%)$, while almost all the remaining areas $(97.8 \%)$ are uninhabited. The inhabited areas include lands used for the following purposes: houses, services, agricultural and cultivable lands inside and outside the administration of the governorates (INP, 2003, pp. 118-127).

It seems that these fast areas haven't been utilized for land reclamation projects, even to compensate for the traditional agricultural lands lost due to building houses randomly all over the country.

\section{1-1 Size of Population in Border Governorates:}

Table (2) indicates the absolute numbers of both population and labour force by sex for the last four censuses, from 1976 to 2006, in addition to the most recent data of mid-2015, as indicated in Figure (1).

It is clearly evident that the five border governorates absorb less than $2 \%$ of the total population as of mid-2015. Again, five Governors are responsible for this very low share of the total population. In absolute terms, the five governorates include less than 2 million persons, which represent a small portion of the capital Cairo. Moreover, about one-fourth of the border governorates population (468 000) is located in one governorate, Matrouh. This simply means that imbalanced population geographical distribution is not limited to the general level, between the Valley and Delta on the one hand and the border governorates on the other, rather, the imbalance is also evident among border governorates themselves. 


\section{Table 2}

$-25-$ 


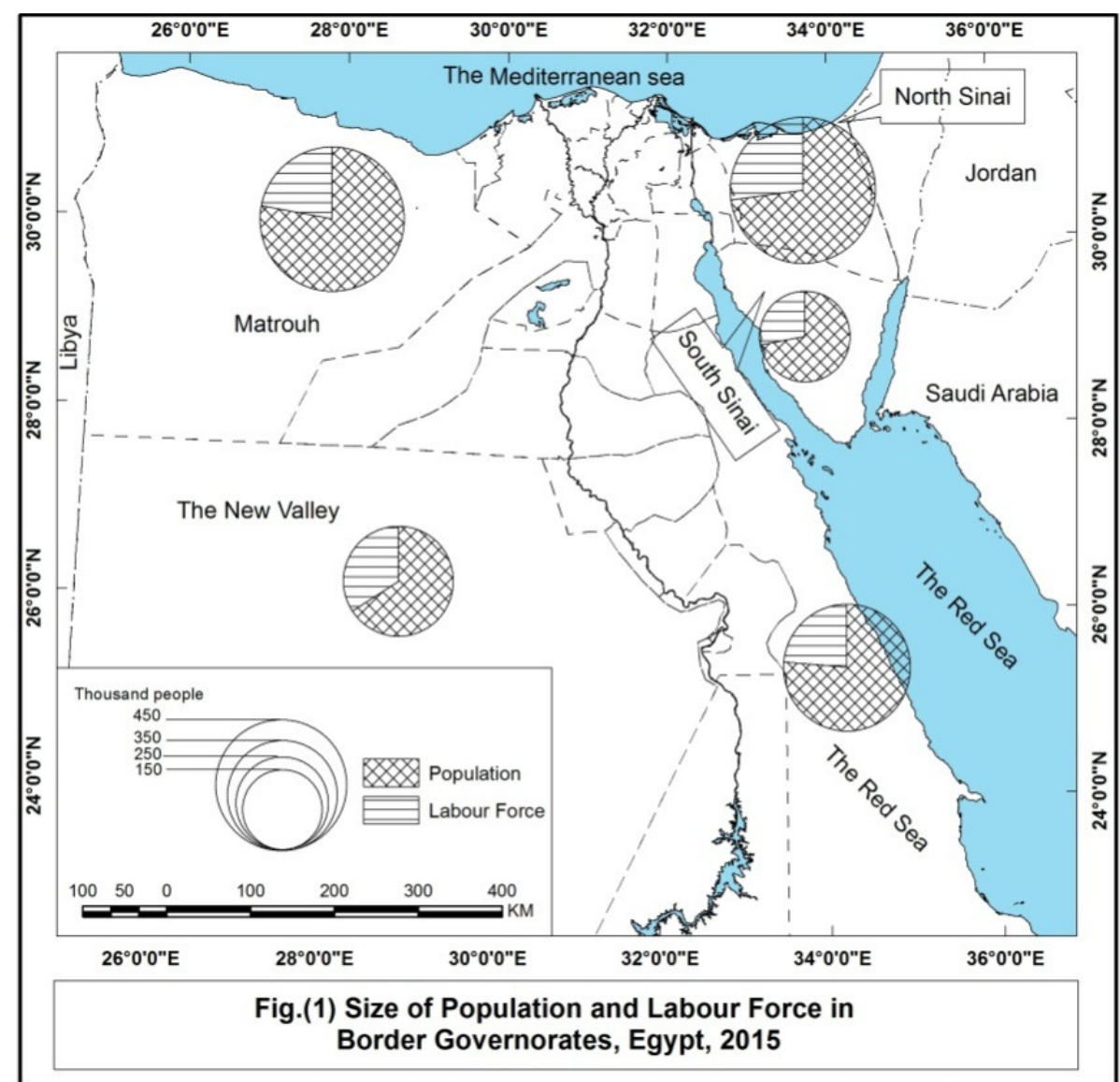

Source:Central Agency for Public Mobilization and Statistics (2016) "Statistical Yearbook, 2016". Issue No. (107), Ref. No. 71-01111-2016

With respect to the percentage of females in the population in general, data of 2015 indicate that percent females of the population in border governorates was $45 \%$ compared to $49 \%$ at the national level. It can be concluded that the presence of females in population in border governorates is slightly lower than that at the national level. This might be a result of temporary internal migration to such governorates, which might be explored more thoroughly in the following parts (INP, 2008, pp. 68-74; El-Bakly, 2016, pp. 7-10; El-Zamly, 2016, pp. 184-188).

\section{1-2 Growth Rates of Population in Border Governorates:}

A quick glance at Table (3) reveals that the growth rates of population in border governorates were nearly double those of the total population during most of the study period 1976-2006, except for the last year (2015), where population growth rates in border governorates were no longer double that of 
the country level, which might be considered as an indicator of inability of border governorates to continue attracting more population (El-Bakly, 2016, pp. 10-14; El-Zamly, 2016, pp. 188-192; INP, 2008, pp. 74-76).

Table 3. Growth Rates of Population (Pop. G. R.), and Labour Force (L. F. G. R.) (15+) by Sex in Border Governorates, Egypt, 1976-2015.

\begin{tabular}{|c|c|c|c|c|c|c|c|c|c|}
\hline \multirow[b]{2}{*}{ Governorate } & \multirow[b]{2}{*}{ Sex } & \multicolumn{2}{|c|}{ 1976-1986 } & \multicolumn{2}{|c|}{ 1986-1996 } & \multicolumn{2}{|c|}{ 1996-2006 } & \multicolumn{2}{|c|}{$2006-2015$} \\
\hline & & $\begin{array}{l}\text { Pop. } \\
\text { G. R. }\end{array}$ & $\begin{array}{l}\text { L. F. } \\
\text { G. R. }\end{array}$ & $\begin{array}{l}\text { Pop. } \\
\text { G. R. }\end{array}$ & $\begin{array}{l}\text { L.F. } \\
\text { G. R. }\end{array}$ & $\begin{array}{l}\text { Pop. } \\
\text { G. R. }\end{array}$ & $\begin{array}{l}\text { L. F. } \\
\text { G. R. }\end{array}$ & $\begin{array}{l}\text { Pop. } \\
\text { G. R. }\end{array}$ & $\begin{array}{l}\text { L. F. } \\
\text { G. R. }\end{array}$ \\
\hline \multirow{3}{*}{ The Red Sea } & $\mathrm{M}$ & 4.58 & 4.91 & 7.47 & 6.89 & 7.12 & 8.12 & 2.29 & -2.28 \\
\hline & $\mathrm{F}$ & 4.54 & 12.39 & 6.07 & 10.09 & 5.01 & 11.67 & 2.95 & 1.23 \\
\hline & $\mathrm{T}$ & 4.56 & 5.42 & 6.89 & 7.17 & 6.33 & 8.54 & 2.50 & 1.71 \\
\hline \multirow{3}{*}{$\begin{array}{l}\text { The New } \\
\text { Valley }\end{array}$} & $M$ & 3.21 & 3.37 & 3.31 & 3.91 & 3.40 & 3.71 & 2.55 & 7.96 \\
\hline & $\mathrm{F}$ & 3.27 & 16.27 & 2.98 & 10.44 & 3.48 & 4.29 & 2.56 & 11.94 \\
\hline & $\mathrm{T}$ & 3.24 & 4.78 & 3.15 & 5.04 & 3.44 & 3.09 & 2.55 & 8.92 \\
\hline \multirow{3}{*}{ Matrouh } & $\mathrm{M}$ & 1.37 & 3.33 & 4.47 & 4.73 & 4.71 & 2.78 & 4.18 & 4.88 \\
\hline & $\mathrm{F}$ & 2.45 & 12.03 & 4.08 & 3.34 & 4.69 & 9.37 & 5.12 & 6.17 \\
\hline & $\mathrm{T}$ & 1.87 & 2.67 & 4.28 & 4.64 & 4.70 & 4.31 & 5.00 & 4.83 \\
\hline \multirow{3}{*}{ North Sinai* } & $\mathrm{M}$ & $26.26^{*}$ & $46.78^{*}$ & 5.12 & 5.88 & 8.39 & 4.31 & 3.17 & 5.69 \\
\hline & $\mathrm{F}$ & $32.50 *$ & $26.51^{*}$ & 4.97 & 16.43 & 8.77 & 2.64 & 3.43 & 8.94 \\
\hline & $\mathrm{T}$ & $28.68 *$ & $02.51 *$ & 5.05 & 7.16 & 8.58 & 2.57 & 3.29 & 7.15 \\
\hline \multirow{3}{*}{ South Sinai } & $\mathrm{M}$ & - & - & 7.36 & 7.13 & 10.85 & 11.63 & 1.02 & -1.99 \\
\hline & $\mathrm{F}$ & - & - & 6.88 & 15.30 & 6.19 & 17.76 & 2.22 & -5.80 \\
\hline & $\mathrm{T}$ & - & - & 7.20 & 7.62 & 9.52 & 12.34 & 1.48 & -2.96 \\
\hline \multirow{3}{*}{$\begin{array}{l}\text { Total Border } \\
\text { Governorates }\end{array}$} & $\mathbf{M}$ & 6.64 & 6.98 & 5.29 & 5.54 & 6.68 & 5.46 & 2.98 & 2.27 \\
\hline & $\mathbf{F}$ & 7.17 & 16.85 & 4.60 & 11.34 & 6.10 & 7.20 & 3.55 & 4.71 \\
\hline & $\mathbf{T}$ & 6.89 & 7.65 & 4.97 & 6.17 & 6.53 & 5.72 & 3.23 & 2.62 \\
\hline \multirow{3}{*}{ Total Egypt } & $\mathbf{M}$ & 2.74 & 2.51 & 2.48 & 2.48 & 2.93 & 2.17 & 2.64 & 2.24 \\
\hline & $\mathbf{F}$ & 2.53 & 6.91 & 2.48 & 6.37 & 2.93 & 3.90 & 2.71 & 8.11 \\
\hline & $\mathbf{T}$ & 2.63 & 2.91 & 2.48 & 2.98 & 2.93 & 2.46 & 2.67 & 3.28 \\
\hline
\end{tabular}

* Including South Sinai.

Sources:

- CAPMAS (1978) "General Census of Population, Housing, and Establishments, 1976", Population Census, Detailed Results, Total Republic, Part One, Ref. No. 93-15111-1978.

- CAPMAS (1988) "General Census of Population, Housing, and Establishments, 1986", Comprehensive Census, Final Results, Vol. 2, Total Republic, ref. No. 863/90/AMT.

- CAPMAS (1998) "General Census of Population, Housing, and Establishments, 1996", Detailed Results of the Population Census, Part One, Total Republic, Ref. No. 1102-1998AMT.

- CAPMAS (2008) "General Census of Population, Housing, and Establishments, 2006", Final Results of the General Census of Population and Housing Conditions, Total Republic. Ref. No. 1102-1103/2008/AMT.

- CAPMAS (2016) "Statistical Yearbook, 2016". Issue No. (107), Ref. No. 71-01111-2016.

\section{1-3 Birth, Death and Natural Increase Rates of Population in Border Governorates:}

The sources of population growth are two: the natural increase and the net migration impact. As for the natural increase itself, it is the net result of both fertility and mortality. In the case of border governorates, the most 
recent data of 2015 in Table (4) indicate that their natural increase rate $(2.6 \%)$ is slightly higher than the national level $(2.3 \%)$, as a result of higher birth rate (31.2), and a lower death rate (4.8), compared to the national level, where the rates were 30.2 and 6.6, respectively. Within border governorates, Matrouh achieved the highest natural increase rate $(4.45 \%)$, while South Sinai achieved the lowest (1.57\%) (El-Bakly, 2016, pp. 10-14; El-Zamly, 2016, pp. 188-192; INP, 2008, pp. 74-76).

Table 4. Distribution of Numbers and Rates of Births, Deaths, and Natural Increase in Border Governorates, Egypt, 2015.

\begin{tabular}{|l|c|c|c|c|c|c|c|}
\hline \multirow{2}{*}{ Governorate } & \multicolumn{2}{|c|}{ Births } & \multicolumn{2}{c|}{ Deaths } & \multicolumn{2}{c|}{ Natural Increase } & \multicolumn{2}{c|}{\begin{tabular}{c} 
Mid-Year \\
Population \\
\cline { 2 - 7 }
\end{tabular}} & No. & $\begin{array}{c}\text { Rate } \\
\text { \%o }\end{array}$ & No. & $\begin{array}{c}\text { Rate } \\
\text { \%o }\end{array}$ & No. & $\begin{array}{c}\text { Rate } \\
\text { \% }\end{array}$ & $\begin{array}{c}\mathbf{2 0 1 5}) \\
\text { The Red Sea }\end{array}$ & 10163 & 29.0 & 1686 & 4.8 & 8477 & 2.42 & 349862 \\
\hline $\begin{array}{l}\text { The New } \\
\text { Valley }\end{array}$ & 6315 & 27.7 & 1135 & 5.0 & 5180 & 2.27 & 227823 \\
\hline Matrouh & 22666 & 49.5 & 2300 & 5.0 & 20366 & 4.45 & 457486 \\
\hline North Sinai & 13206 & 30.0 & 2400 & 5.4 & 10806 & 2.45 & 440397 \\
\hline South Sinai & 3308 & 19.6 & 665 & 3.9 & 2643 & 1.57 & 168479 \\
\hline $\begin{array}{l}\text { Total Border } \\
\text { Governorates }\end{array}$ & $\mathbf{5 5 6 5 8}$ & $\mathbf{3 1 . 2}$ & $\mathbf{8 1 8 6}$ & $\mathbf{4 . 8}$ & $\mathbf{4 6 4 7 2}$ & $\mathbf{2 . 6 0}$ & $\mathbf{1 6 4 4 0 4 7}$ \\
\hline \multicolumn{1}{|c|}{ Total Egypt } & $\mathbf{2 6 8 5 2 7 8}$ & $\mathbf{3 0 . 2}$ & $\mathbf{5 7 3 8 7 9}$ & $\mathbf{6 . 6}$ & $\mathbf{2 1 1 1 3 9 7}$ & $\mathbf{2 . 3 7}$ & $\mathbf{8 8 9 5 7 8 3 3}$ \\
\hline
\end{tabular}

Source: CAPMAS (2016) "Statistical Yearbook, 2016". Issue No. (107), Ref. No. 71-01111-2016.

\section{1-4 Internal Migration to the Border Governorates:}

Contribution of internal migration to the population growth of border governorates can be assessed from Table (5) and Figure (2), which indicate the numbers of those who migrated to different border governorates and the reasons behind such movements. At the general level, the border governorates attracted less than quarter a million (247000) during the intersensal period 1996-2006, representing only 5.2\% of those who migrated at the national level in 2006, a share that is more than double the shares of both population and labour force indicated earlier (2\%), even if the absolute and relative size of those who migrated from border governorates during the same period are not available. As for sex differentials, while percent females among migrants at the national level was $51 \%$, it was only $43 \%$ among those migrating to border governorates, which might indicate that while migration at the national level is of family nature, it is mainly related to males and work in the case of border governorates. This can be investigated in more detail in the following paragraphs. 
Table 5.

$-29-$ 


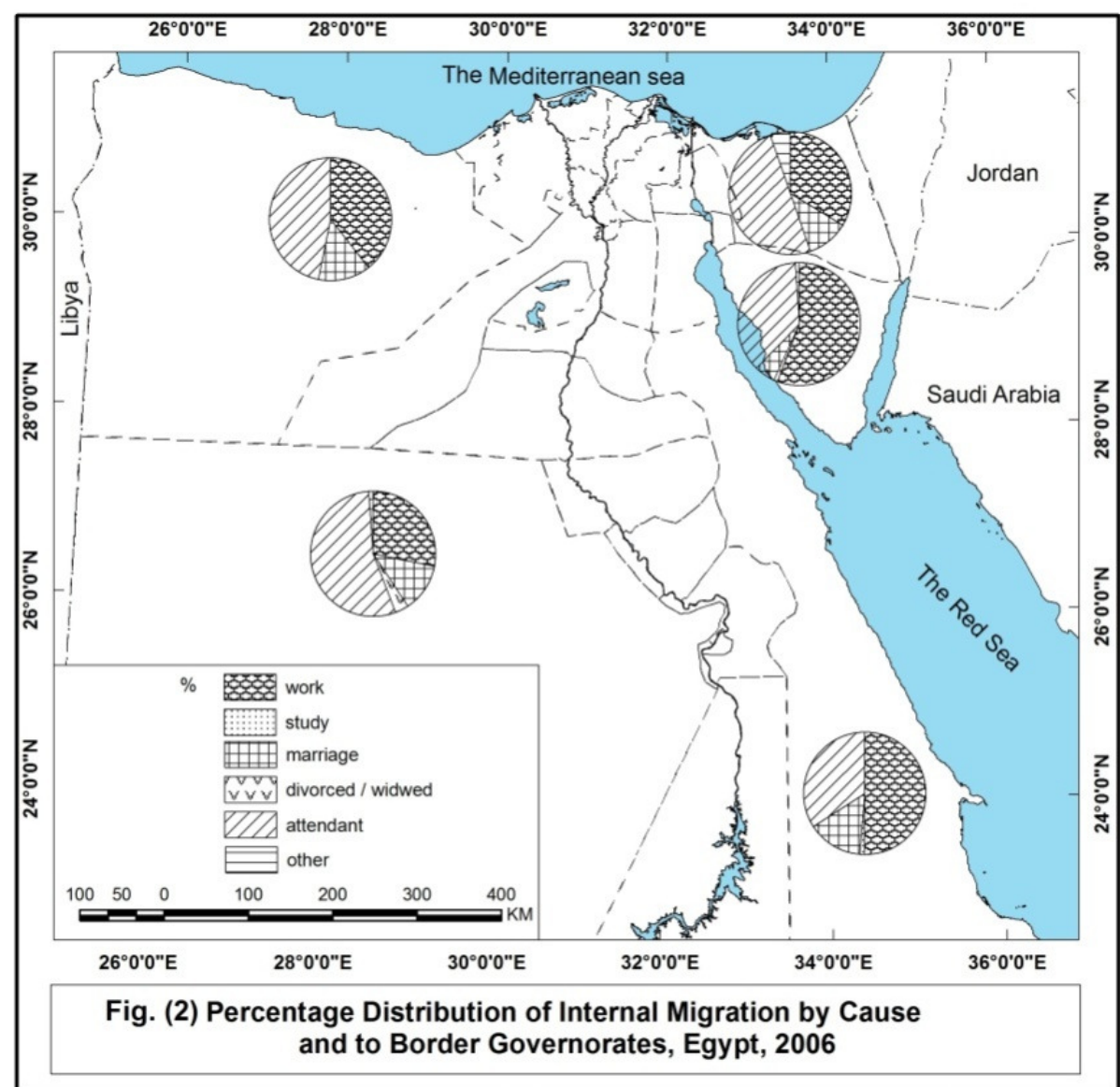

Source: CAPMAS (2016) "Statistical Yearbook, 2016". Issue No. (107), Ref. No. 71-01111-2016.

As for the causes of migration to border governorates, it seems that the major cause of movement is looking for (work) (43\%), followed by (attendance) (42\%), taking into account that the latter are the followers of the earlier. Moreover, marriage is responsible for about (12\%) of the persons who moved to border governorates, which may be attributed also to the major cause of movement (work). By contrast, movement of population to (study) in border governorates contributed less than $1 \%$, which might be of great relevance to the policy implications by the end of the study.

Logically, the causes of migration differ by sex. As indicated earlier, (work) was the major of migration directly and indirectly for total and male migration. As for females, the causes differ greatly in importance, where (attendance) assumes the first rank (65\%), while (marriage) assumes the 
second rank (28\%), with (work) assuming a very low level (4\%) (El Zamly, 2016, pp. 193-199; Hasaneen, 2009, pp. 153-159; INP, 2011, pp. 84-86).

\section{1-5 Urbanization Levels in Border Governorates:}

Although border governorates are sometimes called "desert governorates", due to the large desert areas included in each border governorate, population residence is still divided into rural and urban as usual. In fact, it can be said that the characteristic "rural" in border governorates differs from that adopted in the Nile Valley and Delta, in the traditional sense. Even the characteristic "urban" is not the same, as in most cases small residence areas are declared "urban" for administrative purposes, even if the total number of population is less than many large villages. This can easily explain the fact that urbanization level in border governorates $(68 \%)$ was seemingly higher than that of the national level (43\%) as of 2006 , as indicated in Table (6) and Figure (3). This might be attributed to the shortage of agricultural areas and the related rural life as indicated earlier, rather than to improving life conditions and urbanization in itself.

At the governorate level, it can be seen that while urbanization level was the highest in the Red Sea governorate (96\%), it was the lowest in the New Valley governorate $(48 \%)$. This can be explained by the dominance of tourism activities in the earlier, against the dominance of agricultural activities in the latter, as will be indicated later (Abdel-Hamid, 1994, pp. 711, 51-75; El-Bakly, 2016, pp. 10-12; El-Zamly, 2016, pp. 208-209; INP, 2008, pp. 70-71).

Table 6. Distribution of Population by Urban-Rural Residence in Border Governorates, Egypt, 2006.

\begin{tabular}{|l|l|l|l|l|}
\hline \multirow{2}{*}{ Governorate } & \multirow{2}{*}{ \% Urban } & \multirow{2}{*}{ \% Rural } & \multicolumn{2}{c|}{ Total } \\
\cline { 4 - 5 } & & & \% & \multicolumn{1}{c|}{ No. } \\
\hline The Red Sea & 95.50 & 4.50 & 100.00 & 288661 \\
\hline The New Valley & 48.13 & 51.87 & 100.00 & 187263 \\
\hline Matrouh & 70.58 & 29.72 & 100.00 & 323381 \\
\hline North Sinai & 60.47 & 39.53 & 100.00 & 343681 \\
\hline South Sinai & 50.67 & 49.33 & 100.00 & 150088 \\
\hline Total Border Governorates & 67.90 & 32.09 & 100.00 & 1293074 \\
\hline Total Egypt & 43.09 & 56.91 & 100.00 & 72798031 \\
\hline
\end{tabular}

Source: CAPMAS (2016) "Statistical Yearbook, 2016". Issue No.(107), Ref. No. 71-01111-2016. 


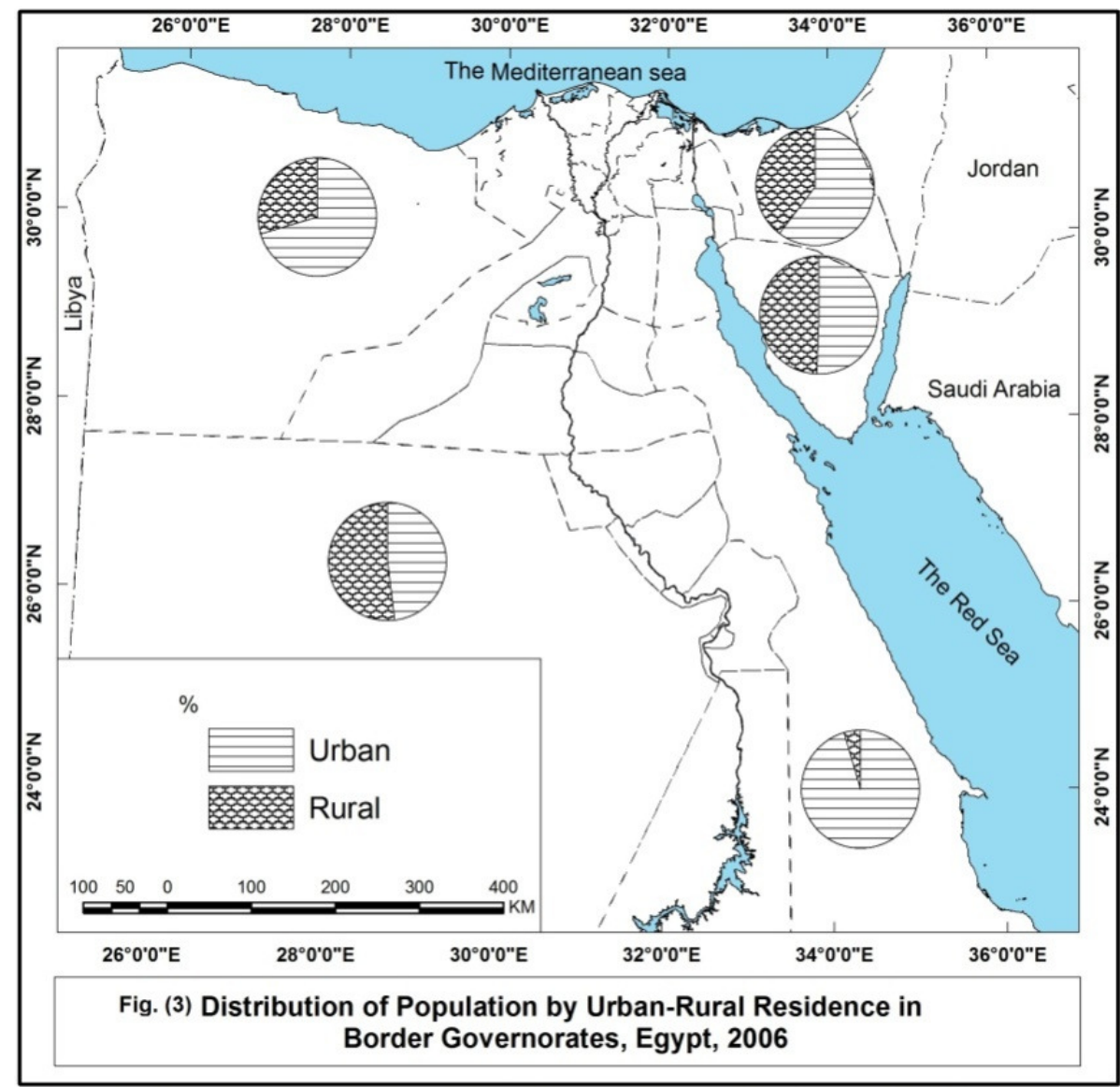

Source: CAPMAS (2016) "Statistical Yearbook, 2016". Issue No. (107), Ref. No. 71-01111-2016.

\section{2) Levels, Patterns and Trends of the Labour Force in Border Governorates:}

As for the labour force, again the share of the border governorates of total labour force in Egypt is only 2\%, which is not different from the share of total population. Simply, it can't be said that border governorates are attracting population or providing job opportunities until recently. Again, about one-fifth of the administrative apparatus is responsible for only $2 \%$ of the labour force in border governorates, as already indicated in Table (2) and Figure (1).

It has already been indicated that the total number of labour force in border governorates amounted to 592000 in 2015, compared to 479000 in 2006, with an increase of only 113000 in about 9 years. As a result, the share of border governorates of total labour force did not exceed the level of $2 \%$, which is similar to that of the total population, as stated earlier. 
As for sex differentials, percent female among labour force in border governorates was $20 \%$ in 2015 , compared to $18 \%$ in 2006 . At the national level, the equivalent percentages were $24 \%$ and $18 \%$, respectively. This means that the share of females in the labour force in border governorates is increasing, but slower than that of the national level. This may have relevance to the extent of availability of job opportunities for females in border governorates compared to the national level.

On the other hand, growth rates of labour force in border governorates are more than double those of the country level, during most of the study period, while they became even lower than the country level in 2015. This supports the above-mentioned conclusion that the border governorates are no longer attractive to the population and labour force, as indicated earlier in Table (3).

As for the growth rates of the female labour force, all pervious studies indicate that they are higher than their male counterparts at the country level, which is clearly evident in the Table. Moreover, such rates were more than double those of their male counterparts in border governorates, except for 2015 , where the growth rate of female labor force in border governorates $(4.7 \%)$ was lower than that of the previous intercensal period (7.2\%).

With respect to the growth rate of female labour force during the period 2006-2015, it was about 5\% in border governorates, compared to $8 \%$ at the national level, which is largely greater than the growth rates of their male counterparts: being $2.3 \%$ and $2.2 \%$, respectively.

\section{2-1 Theoretical Participation of the Population in Economic Activities:}

Theoretically, in the literature of labour force studies, the extent of population participation in economic activities can be measured using crude activity rates, refined activity rates, and age-specific activity rates. While the second is more revealing than the first, as it excludes population under age $(-15)$, the third is more accurate than the second, as it is measured by fiveyear age groups, with an internationally familiar pattern, especially for males.

Depending on the aforementioned analysis of the size of both population and labour force in the previous sections, one can easily proceed to analysis of the labour force in border governorates, beginning with the extent of participation of population in economic activities, measured by the refined activity rates indicated in Table (7). As expected, about two-thirds of the population aged 15+ were participating in economic activities at the national level in 2006, while it was largely lower in 1976 (45\%) and increasing during the study period. As for the border governorates in general, the same level was attained in 2006 (65\%), but from a very low level in 1976 (25\%), indicating that participation in economic activities is increasing rapidly in border governorates, compared to the national level. 
Table 7. Refined Activity Rates (15+) by sex in Border Governorates, Egypt. 1976-2006.

\begin{tabular}{|l|c|c|c|c|c|}
\hline \multicolumn{1}{|c|}{ Governorate } & Sex & $\mathbf{1 9 7 6}$ & $\mathbf{1 9 8 6}$ & $\mathbf{1 9 9 6}$ & $\mathbf{2 0 0 6}$ \\
\hline \multirow{3}{*}{ The Red Sea } & $\mathrm{M}$ & 79.86 & 82.86 & 77.78 & 76.02 \\
& $\mathrm{~F}$ & 4.06 & 8.94 & 13.31 & 26.96 \\
& $\mathrm{~T}$ & 46.43 & 50.90 & 52.10 & 52.17 \\
\hline \multirow{3}{*}{ The New Valley } & $\mathrm{M}$ & 78.83 & 77.26 & 81.43 & 77.34 \\
& $\mathrm{~F}$ & 3.37 & 11.86 & 24.86 & 9.89 \\
& $\mathrm{~T}$ & 41.93 & 45.04 & 54.04 & 45.57 \\
\hline \multirow{3}{*}{ Matrouh } & $\mathrm{M}$ & 81.87 & 82.27 & 84.14 & 74.88 \\
& $\mathrm{~F}$ & 2.68 & 6.72 & 6.19 & 18.30 \\
& $\mathrm{~T}$ & 45.42 & 45.92 & 47.39 & 47.55 \\
\hline \multirow{3}{*}{ South Sinai } & $\mathrm{M}$ & $90.92^{*}$ & 74.47 & 79.48 & 93.30 \\
& $\mathrm{~F}$ & $1.50^{*}$ & 6.20 & 19.41 & 53.41 \\
& $\mathrm{~T}$ & $54.95^{*}$ & 41.27 & 50.70 & 83.78 \\
\hline \multirow{3}{*}{ Total Border Governorates } & $\mathrm{M}$ & - & 91.74 & 86.41 & 71.66 \\
& $\mathrm{~F}$ & - & 7.33 & 16.78 & 15.93 \\
& $\mathrm{~T}$ & - & 62.70 & 63.21 & 44.30 \\
\hline \multirow{2}{*}{ Total Egypt } & $\mathrm{M}$ & 44.22 & 79.95 & 81.33 & 85.97 \\
& $\mathrm{~T}$ & 0.12 & 8.08 & 15.76 & 25.90 \\
& $\mathrm{M}$ & 80.00 & 71.90 & 77.30 & 85.97 \\
& $\mathrm{~F}$ & 6.46 & 9.87 & 14.46 & 25.90 \\
& $\mathrm{~T}$ & 44.71 & 33.39 & 46.46 & 65.00 \\
\hline
\end{tabular}

* Including South Sinai.

Sources:

- CAPMAS (1978) "General Census of Population, Housing, and Establishments, 1976", Population Census, Detailed Results, Total Republic, Part One, Ref. No. 93-15111-1978.

- CAPMAS (1988) "General Census of Population, Housing, and Establishments, 1986", Comprehensive Census, Final Results, Vol. 2, Total Republic, ref. No. 863/90/AMT.

- CAPMAS (1998) "General Census of Population, Housing, and Establishments, 1996", Detailed Results of the Population Census, Part One, Total Republic, Ref. No. 1102-1998-AMT.

- CAPMAS (2008) "General Census of Population, Housing, and Establishments, 2006", Final Results of the General Census of Population and Housing Conditions, Total Republic. Ref. No. 1102-1103/2008/AMT.

- CAPMAS (2016) "Statistical Yearbook, 2016". Issue No. (107), Ref. No. 71-01111-2016.

As for sex differentials, the same levels and trends are applicable to both sexes, but the levels were lower and the trends were faster in the case of females, compared to males, at both national and border governorates levels. Specifically, female participation in economic activities increased from less than $1 \%$ in 1976 to about $26 \%$ in 2006 in border governorates compared to $6 \%$ and $26 \%$ at the national level.

Among border governorates, females seem to be most active in North Sinai (53\%), while they were the least active in Matrouh (10\%), which might be explained by dominance of tourism activities in the earlier, against dominance of agricultural activities in the later, as stated earlier. 


\section{2-2 Practical Participation of the Population in Economic Activities:}

Practically, not all population active in the labour market are actually employed, rather, a part of such activity is devoted to seeking for work, without actually finding and practicing it. Here appears the problem of unemployment, which indicates the extent of success in finding and practicing work, at the individual level; and the extent of exploiting available human resources at the society level.

Table (8) indicates unemployment rates by sex in border governorates during the period 1976-2015. It indicates that unemployment rate at the national level exceeded the level of 5\% only in the census of 1986, where it attained the highest level during the intercensal periods (11\%), with a decreasing trend to $9.7 \%$ in 2006 , where it increased again to the highest level ever (12.8) in 2015. As for border governorates, unemployment rate was about 7\% during the period 1986-2006, which was lower than that of the national level by about 4 percentage points. Unfortunately, by 2015 the two rates became closer: being $12.8 \%$ at the national level, against $11.7 \%$ in border governorates. This might indicate that border governorates are currently suffering higher unemployment rates as the rest of the country, and are no longer able to attract more population and provide job opportunities, neither for residents, nor for migrants.

Within border governorates, it seems that The Red Sea Governorates was the most suffering, with an unemployment rate $(20.5 \%)$ that is higher even than the national level (12.3\%), followed by the New Valley Governorate (14.3\%); while South Sinai Governorate was the least suffering (3.2\%), preceded by Matrouh Governorate (7.7\%).

As for sex differentials, Table (8) also indicates that while female unemployment rate at the national level slightly fluctuated around one fourth of the female labour force during the study period (25\% in 1986 and $24 \%$ in 2015), it nearly doubled during the same period (16.7\% in 1986 and $31.3 \%$ in 2015) in border governorates. this means that female governorates in border governorates are more suffering than their counterparts at the national level. In other words, about one-fourth of female labour force $(24 \%)$ is idle at the national level, while one-third of it $(31 \%)$ is idle in border governorates: being the highest in the Red Sea Governorate (48\%), followed by the New Valley Governorate (37\%). This is the reason behind detailing the analysis of labour force into theoretical and actual participation in economic activities, especially for females.

In fact, Egypt has been suffering high and increasing unemployment rates since 1986, when unemployment rates exceeded the theoretical level of 
(5\%). Since 2011, however, the problem became more aggravated, where both external and internal military, political and socio-economic conditions became no longer favorable for job creation, especially those border governorates that used to depend on tourism, such as the Red Sea.

Table 8. Unemployment Rates by Sex in Border Governorates, Egypt, 1976-2015.

\begin{tabular}{|l|c|c|c|c|c|c|}
\hline \multicolumn{1}{|c|}{ Governorate } & Sex & $\mathbf{1 9 7 6}$ & $\mathbf{1 9 8 6}$ & $\mathbf{1 9 9 6}$ & $\mathbf{2 0 0 6}$ & $\mathbf{2 0 1 5}$ \\
\hline \multirow{3}{*}{ The Red Sea } & $\mathrm{M}$ & 0.22 & 8.07 & 6.23 & 4.39 & 14.4 \\
& $\mathrm{~F}$ & 0.17 & 14.37 & 14.88 & 15.38 & 48.0 \\
& $\mathrm{~T}$ & 0.22 & 8.55 & 7.24 & 5.92 & 20.5 \\
\hline \multirow{3}{*}{ The New Valley } & $\mathrm{M}$ & 2.18 & 8.23 & 7.50 & 6.77 & 4.7 \\
& $\mathrm{~F}$ & 6.46 & 30.16 & 24.57 & 18.98 & 37.4 \\
& $\mathrm{~T}$ & 2.45 & 11.08 & 10.46 & 9.83 & 14.3 \\
\hline \multirow{3}{*}{ Matrouh } & $\mathrm{M}$ & 1.67 & 3.73 & 4.68 & 5.62 & 6.2 \\
& $\mathrm{~F}$ & 6.23 & 4.36 & 6.76 & 9.16 & 20.3 \\
& $\mathrm{~T}$ & 1.80 & 3.77 & 4.88 & 5.98 & 7.7 \\
\hline \multirow{3}{*}{ Sorth Sinai } & $\mathrm{M}$ & $3.20 *$ & 5.86 & 5.48 & 5.09 & 5.1 \\
& $\mathrm{~F}$ & $6.90 *$ & 13.25 & 12.05 & 10.85 & 27.3 \\
& $\mathrm{~T}$ & $3.68 *$ & 6.40 & 6.28 & 6.16 & 10.6 \\
\hline \multirow{3}{*}{ Total Border Governorates } & $\mathrm{M}$ & - & 1.79 & 3.29 & 4.78 & 1.3 \\
& $\mathrm{~F}$ & - & 6.74 & 8.10 & 9.46 & 12.2 \\
& $\mathrm{~T}$ & - & 1.99 & 3.74 & 5.49 & 3.2 \\
\hline & $\mathrm{F}$ & 1.58 & 5.78 & 5.52 & 5.16 & 6.6 \\
& $\mathrm{~T}$ & 4.63 & 16.71 & 15.02 & 13.32 & 31.3 \\
& $\mathrm{M}$ & $\mathbf{3 . 3 1}$ & $\mathbf{1 0 . 0 7}$ & $\mathbf{8 . 8 8}$ & $\mathbf{7 . 6 8}$ & $\mathbf{9 . 4}$ \\
& $\mathrm{F}$ & $\mathbf{1 5 . 4 3}$ & $\mathbf{2 5 . 4 8}$ & $\mathbf{2 2 . 3 7}$ & $\mathbf{1 9 . 2 5}$ & $\mathbf{2 4 . 2}$ \\
& T & $\mathbf{4 . 1 8}$ & $\mathbf{1 1 . 0 8}$ & $\mathbf{1 0 . 4 0}$ & $\mathbf{9 . 7 2}$ & $\mathbf{1 2 . 8}$ \\
\hline
\end{tabular}

* Including South Sinai.

Sources:

- CAPMAS (1978) "General Census of Population, Housing, and Establishments, 1976", Population Census, Detailed Results, Total Republic, Part One, Ref. No. 93-15111-1978.

- CAPMAS (1988) "General Census of Population, Housing, and Establishments, 1986", Comprehensive Census, Final Results, Vol. 2, Total Republic, ref. No. 863/90/AMT.

- CAPMAS (1998) "General Census of Population, Housing, and Establishments, 1996", Detailed Results of the Population Census, Part One, Total Republic, Ref. No. 1102-1998AMT.

- CAPMAS (2008) "General Census of Population, Housing, and Establishments, 2006", Final Results of the General Census of Population and Housing Conditions, Total Republic. Ref. No. 1102-1103/2008/AMT.

- CAPMAS (2016) "Statistical Yearbook, 2016". Issue No. (107), Ref. No. 71-01111-2016.

\section{2-3 Age-Structure of the Unemployed in Border Governorates:}

Unemployment can be further analyzed by age to investigate whether this passive phenomena affects all labour force or specific age groups. Table (9) presents the age-specific unemployment rates in border governorates for the last two census years 1996 and 2006. 
Table 9.

-37- 
Figures of Table (9) indicate that unemployment mainly affects the first three age groups, from the age 15 to 29 , covering the first 15 years of the economically active life. At the national level, it seems that between onefourth and one-third of the labour force (28\% in 1996 and 33\% in 2006) in the first age-group, 15-19, are unemployed, (against 25\% and 29\% in border governorates), including those entering the labour market for the first time, with different educational levels, including those graduated in different secondary schools. The same applies more or less - at the national level and in border governorates - to the second age group 20-24, which includes those graduated in higher than secondary institutions and universities.

Strikingly, more than half the female labour force aged 15-19 are unemployed at the national level (58\% in 1996 and 55\% in 2006), compared to $51 \%$ in 1996 and $50 \%$ in 2006 in border governorates. Thus, it can be simply assured that actual female participation in economic activity is largely less than the theoretical levels everywhere in the country.

Unemployment can be further analyzed by age to investigate whether this passive phenomena affects all labour force or specific age groups. Table (9) presents the age-specific unemployment rates in border governorates for the last two census years 1996 and 2006.

\section{2-4 Educational Levels of the Unemployed:}

The earlier analysis of unemployment rates by age groups revealed that most unemployed persons belong to the youth age groups (15-39). Also, it was stated that these age groups include persons graduated in different educational levels, especially those with secondary, higher than secondary, university, and higher than university certificates. Here, Table (10) and Figures (4) and (5) present the educational status of the unemployed for the years 2006 and 2015.

At the national level, more than half the unemployed belonged to the category of secondary and higher (58\%), for both sexes (58\% for males and 59\% for females) in 2006. However, the relative share of this category declined slightly in 2015 to about 50\% (47\% for males against 53\% for females).

With respect to border governorates in, it is clear that border governorates were better than the national level as for unemployment of secondary education graduates, where they had lower percentages for both sexes in the two years. Unfortunately, this apparently false improvement in the situation can be proved by observing that the relative share of unemployed with university education and above increased from $21 \%$ in 2006 to $32 \%$ in 2015 at the national level, and from $14 \%$ to $32 \%$ in border governorates: the situation being more worse for females than males at the national level in general and in border governorates in particular. 
Table 10.

$-39-$ 

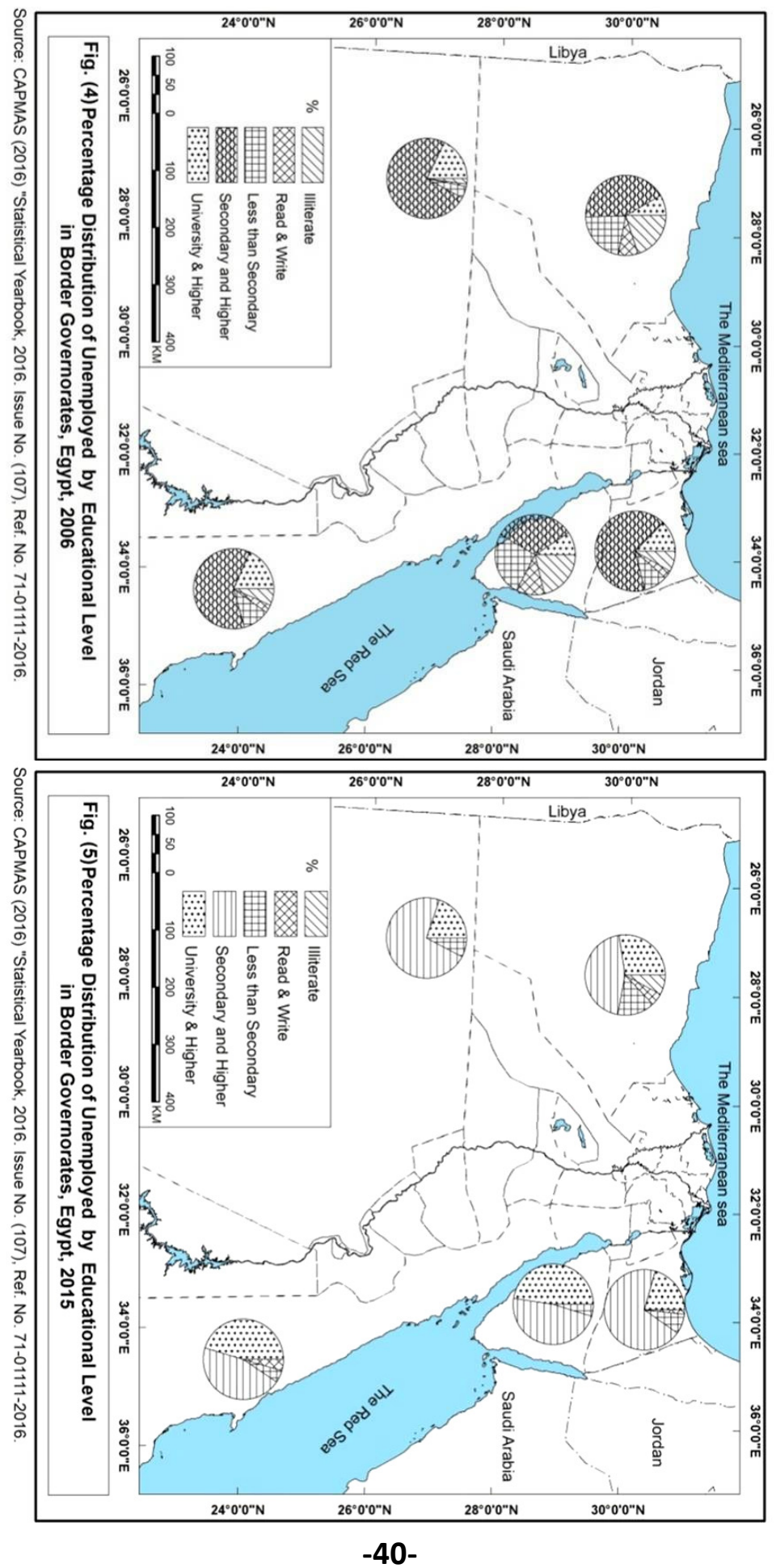
In sum, it can be said that border governorate are no exception as for the levels, patterns and trends of unemployment, that are prevalent at the national level, especially in recent years (El-Bakly, 2016, pp. 31-39; INP, 2003, pp. 174-185; INP, 2008, pp. 83-87; Zayyan, 2013, pp. 17-52).

\section{3) Socio-Economic Characteristics of the Labour Force and Workers in Border Governorates:}

Having investigated the levels, patterns, trends and characteristics of the population of the border governorates, on the one hand; and the levels, patterns and trends of the labour force in the same governorates, on the other; it remains to investigate the socio-economic characteristics of the labour force in general, and the workers in particular. This can be achieved by investigating the structural changes in the educational levels, employment statuses, institutional sectors, occupations, and economic sectors, respectively.

\section{3-1 Educational Structure of the Labour Force in Border Governorates:}

Initially, it must be clearly stated that the educational levels investigated earlier are those of the unemployed only, rather than the whole labour force, which are investigated here, with different years (1976 and 2006). In fact, Table (11) and Figures (6) and (7) document the most positive development as far as the population and labour force in Egypt are concerned. Regardless of the level of actually utilizing labour force in economic activities, i.e. unemployment rates discussed earlier, it is evident that the educational status of the Egyptian population in general, and labour force in particular is rapidly improving. This is supported by the fact that while the relative share of inferior educational levels (illiterate, and read \& write) are decreasing, the relative shares of higher educational levels (secondary and University education) are increasing, during the whole study period. This applies to the total and male labour force in general, and to female labour force in particular, at the national level, and in border governorates.

For border governorates in general, the levels, patterns, and trends of educational status is more or less similar to those of the national level. Within border governorates, it seems that South Sinai is the most advantageous, while Matrouh is the least advantageous, as far as the educational status is concerned.

As for sex differentials, it seems again that female labour force is better educated than the male counterpart at both the national and regional levels, and in each border governorate. 
Table 11.

$-42-$ 

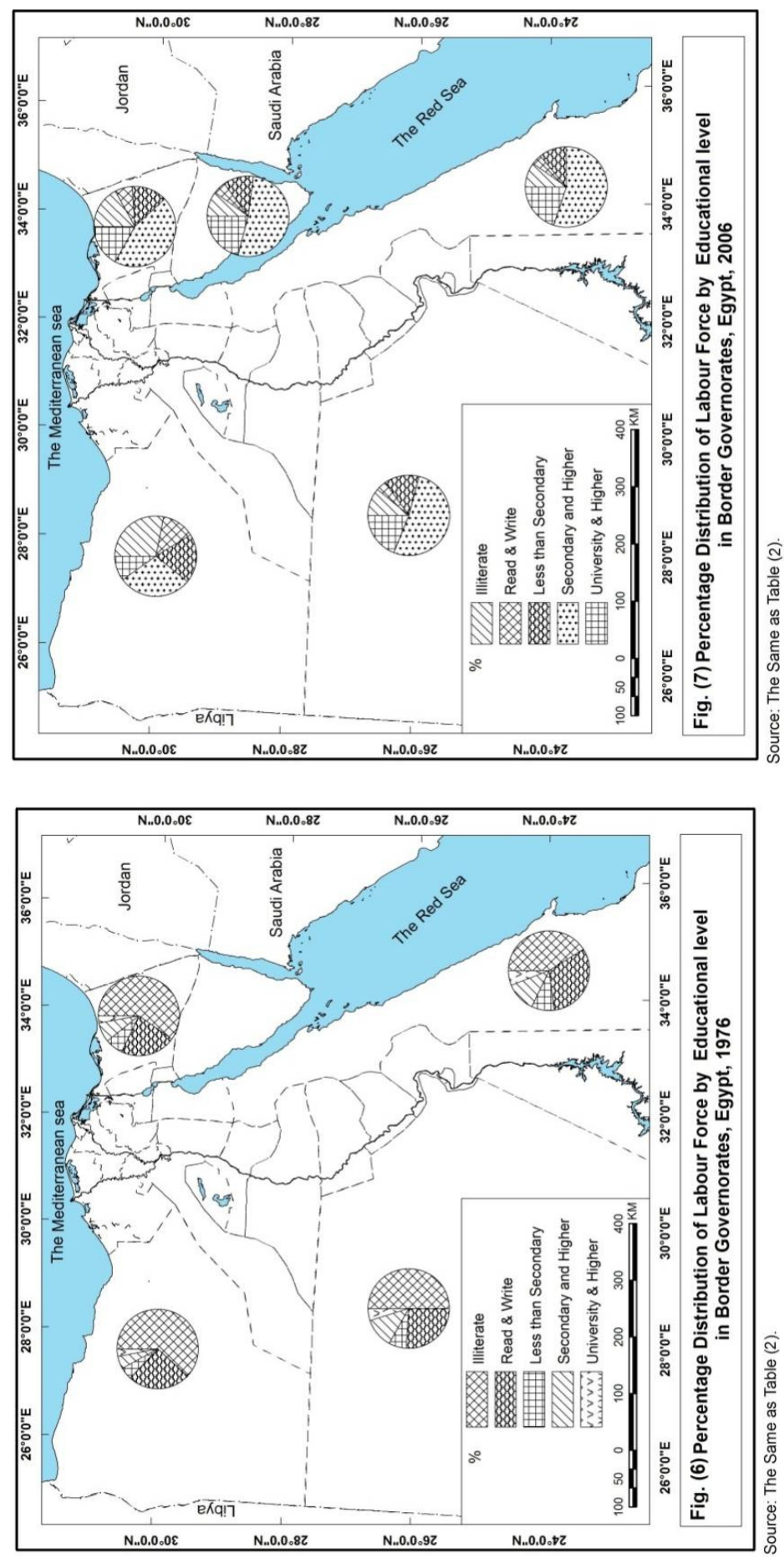

$-43-$ 
Comparison between the educational status of the labour force in general, and that of the unemployed in particular, especially of females - as presented in Table (10) and Figures (4) and (5) earlier - raises speculation about the relation between improvement of the educational status and actual participation in economic activities. In turn, this raises questions as for the trade-offs between spending on education, on the one hand, and spending on creating job opportunities, on the other. Unfortunately, deciding such speculation and questions lies beyond the scope of the present study.

\section{3-2 Employment Status of the Workers in Border Governorates:}

Traditionally, it was the rule in labour force studies to deal with the employment status of the labour force as a whole, but since unemployment rates have assumed high and increasing rates, some researchers prefer to concentrate on the development of the employment status of those who are actually working, i.e. the workers, excluding those who are unemployed. This can be considered a kind of standardization to achieve more accuracy in assessing the actual development of the employment status.

It is clear from Table (12) and Figure (8) that the employment status of the workers is dominated by the category of (Wage Workers), at the national level, for border governorates in general, and for each border governorate, especially in 2006. The relative share of this category increased from about $70 \%$ in 1996 to about $90 \%$ in 2006, at the national level, while it increased faster (form 86 to 92\%) for the same period in border governorate. By contrast, the category of (Unpaid Workers) not only has the lowest relative share, but also is about to vanish, at the national level (from 3 to 1\%) and in border governorates (from 2 to $1 \%$ ).

Another contrast exists between the two categories of "Own-Account Workers" and "Employers" - which relates to the development of the economy in general, on the one hand, and the average size of the project in particular, on the other - where the first decreases rapidly, while the second increases slowly. As for "Own-Account Workers", its relative share at the national level decreased slower (from 20 to 5\%) than that of border governorate (from 24 to 4\%) during the study period 1996-2006. As for the category of "employers", it seems that both the low levels and slow trends are similar at the national and regional levels.

As expected, sex differentials are also evident at both levels, where female workers appear largely in the category of "Wage Workers", and slightly in the category of "Employers". 
Table 12.

$-45-$ 


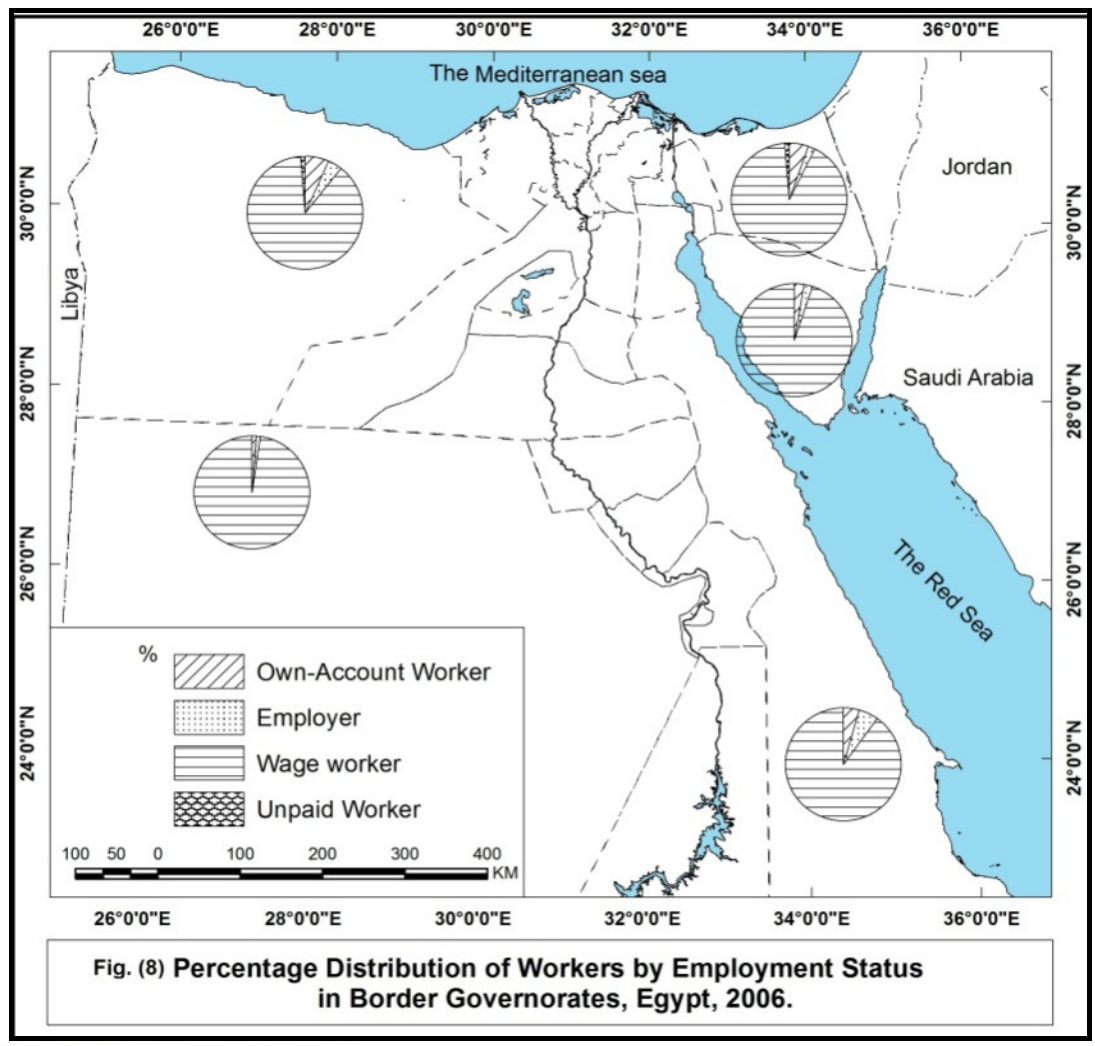

Source: The Same as Table (2).

\section{3-3 Institutional Status of the Workers in Border Governorates:}

The institutional structure of the workers indicates the pattern of ownership, administration, and organization of participation of the workers in economic activities. Moreover, it indicates the nature and transformation of the economic system between the two extremes of capitalism and socialism. As expected, Table (13) and Fig. (9) reveal that the "private sector" continued to be the major job provider, with a rapidly increasing share at both the national level (from 30\% in 1996 to $73 \%$ in 2006), and in border governorates (from 24\% in 1996 to 63\% in 2006). The same high levels and increasing trends apply to the second major employer - the "government sector" - whose relative share more than doubled (from $11 \%$ to $25 \%$ ) at the national level, compare to its lower share and faster increasing trend in border governorates (from 8\% to 29\%). As for the sector of "public works", it seems that its relative share was contracting rapidly at the national level (from 14\% to 2\%), and in border governorates as well (from 17\% to 35) during the study period. This might be a direct result of adopting the strategy of "privatization", which expands the role of the "private sector" at the expense of both the government and the public sectors. 
Table 13.

$-47-$ 


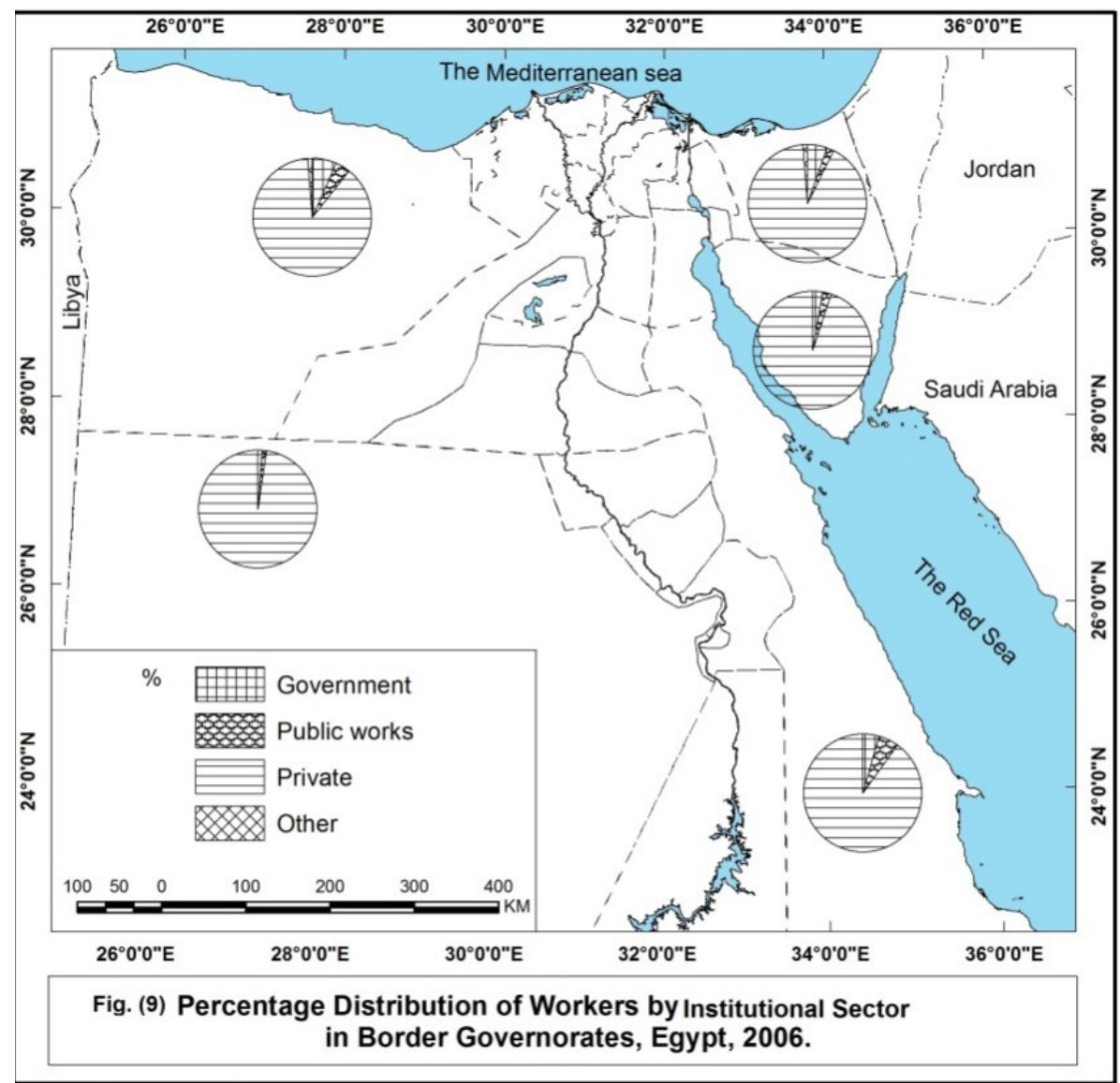

Source: The Same as Table (2).

As for female workers, it seems that the "government sector" became the major job provider in border governorates - where more than half the female workers (56\%) belonged to that sector in 2006, compared to $34 \%$ in $1996-$ followed by the "private sector" with a relatively high and slightly decreasing share (from $44 \%$ to $42 \%$ ).

Within border governorates, the aforementioned levels, patterns, and trends apply without major exceptions.

\section{3-4 Occupational Status of the Workers in Border Governorates:}

In general, the occupational structure of the labour force, or workers, indicates the structure of skills available in a specific society at a specific time point or period. In turn, the occupational structure itself is a result of the interaction between education and training on the one hand, and the level and 
trend of socio-economic development, on the other. It has already been indicated that the educational structure of both the labour force and the unemployed persons was improving during the study period. Logically, such developments are expected to be reflected in an improvement in the occupational structure of the workers during the study period. In particular, it is expected to have a shift from inferior occupations (blue-collar workers) to superior occupations (white-collar workers).

According to expectations, the first improvement in the occupational structure of the workers at the national and regional levels is clearly evident in both Table (14) and Figure (10), where the category of "unclassified occupations" is about to disappear, as its relative share dropped from about $10 \%$ in 1996 to less than $1 \%$ in 2006 , at the national level, as well as in border governorates. This might refer to an improvement in the awareness of both enumerators and workers as for the accurate classification of the occupations, especially among female workers, as the relative share of this category was very high in $1996(22 \%)$.

It is manifested that occupational groups exchanged their ranks between the national level and the regional level during the study period, as occupations of the agricultural sector assumed the first rank in 1996 (27\%), but retreated to the second rank in 2006 (26\%), to be preceded by the category of workers in the manufacturing and transport sector in 2006 (33\%), compared to $23 \%$ in 1996 , at the national level.

As for the border governorates, the first rank - with an increasing trend was occupied by workers with the white collar occupations (Scientific, professional, technical, administrative, and managerial workers) in both census years (being 28\% in 1996 and $31 \%$ in 2006). This is greatly consistent with the conclusions of the institutional structure of the workers presented above, where the government sector was a major player in border governorates, especially for female workers.

As for sex differentials in the occupational structure of the workers, it seems that the improvement of the educational structure of the female labour force - presented earlier - has largely affected the occupational structure of the female workers, as the white collar occupations assumed the first rank in both census years (42\% in 1996 and 51\% in 2006). Again, most of such occupations require higher education, on the one hand, and are mostly provided by the governmental sector, on the other. 
Table 14.

$-50-$ 


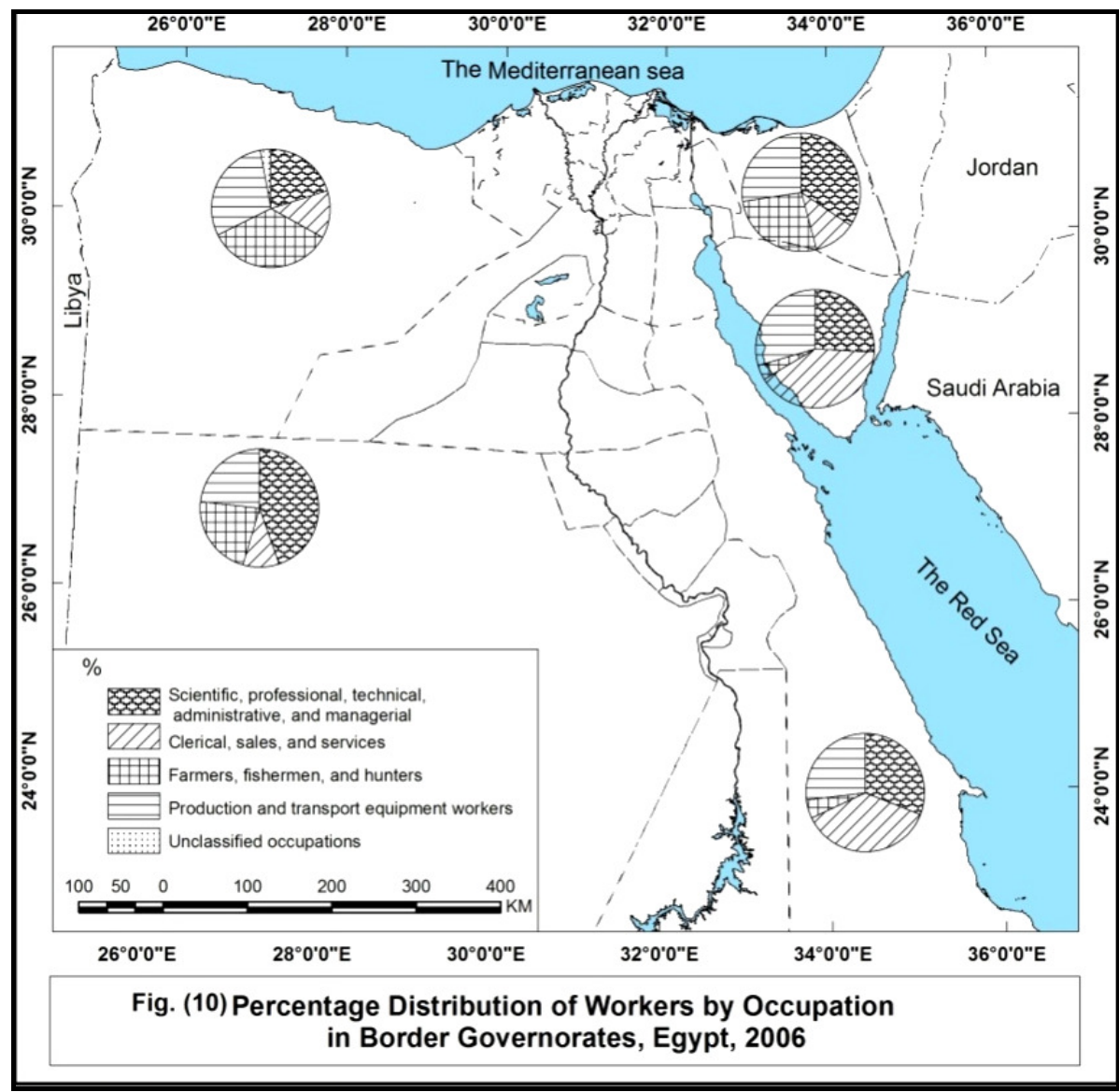

Source: The Same as Table (2).

\section{3-5 Classification of Workers by Economic Sector in Border Governorates:}

Classification of the workers - in any society in a specific time period or point - by the economic sectors to which they belong, indicates the human face of the economic situation of the society. In fact, it simply indicates the number of workers who actually produced the goods and services for the society in the specified time period or point. By definition, productivity - and competitiveness in turn - is the product of dividing the value of goods and services produced by the number of workers who produced them, during the specified time period.

Different economic development theories refer to the economic sectors transformations experienced across different development stages: from primary to secondary sectors, then from secondary to tertiary sectors. From 
both Table (15) and Figure (11), one can trace the structural transformations in the classification of workers by economic sectors during the study period 1996-2006. As expected, at the national level, the relative shares of both "agriculture" and "manufacturing" declined from 31\% and 15\% in 1996 to $26 \%$ and 135 in 2006, respectively. By comparison, the relative share of both "trade and transportation" and "community services" increased from $16 \%$ and $24 \%$ in 1996 to $12 \%$ and $27 \%$ in 2006 . In conclusion, it can be said that while "agriculture" was the first sector in 1996, "community services" became the first sector in 2006. Another conclusion is that the relative shares of different economic sectors - as for creating jobs and absorbing workers - became more balanced in 2006, compared to that of 1996.

In border governorates, however, the "community services sector" was the dominant one in both census years, with an increasing trend, from $29 \%$ in 1996 to $33 \%$ in 2006. Logically, the relative share of "agriculture" was lower and rapidly decreasing in such border and "desert" governorates, from $26 \%$ in 1996 to $15 \%$ in 2006. In addition, it seems that there were no large desert reclamation projects in border governorates, during the study period. Moreover, the border governorates have a higher and faster increasing relative share (from $20 \%$ in 1996 to $33 \%$ in 2006) for the sector of "trade and transportation, compared to the national level. This might be attributed to the large land areas and the highly dispersed communities in the border governorates. Accordingly, the relative shares of different economic sectors - as for creating jobs and absorbing workers in border governorates - became less balanced in 2006, compared to that of 1996, where only two out of the seven sectors - "trade and transportation" and "community services" - absorbed about two-thirds of the workers, with equal shares $(33 \%)$.

Within border governorates, both Table (15) and Figure (11) indicate that about ten years ago the classification of workers by economic sectors was not only different from that of the national level, but also differs from one governorate to another. For example, while the sector of "trade and transportation" was the dominant one in the two largest governorates (58\% in the New Valley and 36\% in the Red Sea), the sector of "community sector" was the dominant in Matrouh (57\%) and South Sinai (41\%). Only North Sinai kept "agriculture" as the major sector for workers in both years (35\%) (El-Zamly, 2016, pp. 216-219; Institute of National Planning, 2003, pp. 185196; Ministry of Planning, 1994, pp. 20, 32, 86; Ministry of Planning, 1996, pp. 160-179; Zayyan, 2013, pp. 82-109). 
Table 15.

$-53-$ 


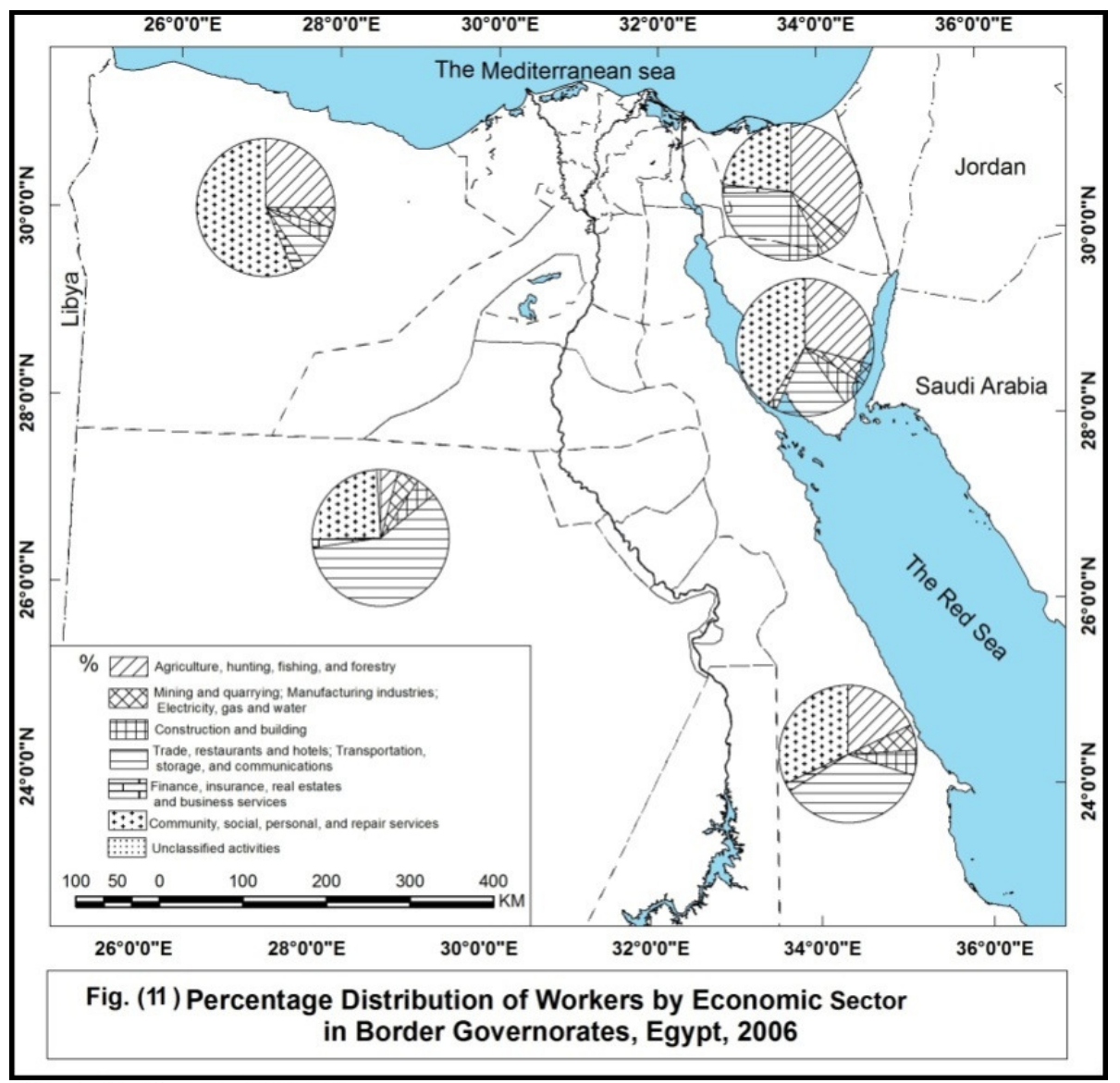

Source: The Same as Table (2)

\section{4) Conclusions and Recommendations}

In the light of the previous analysis of different tables and figures, and within the limits of the study presented above, the final conclusions and recommendations of the present study can be summarized as follow:

\section{4-1 Conclusions:}

The five border governorates still assume about $79 \%$ of the land area of the country. The total number of population in border governorates amounted to about 1669 thousand persons as of mid-2015, representing less than $2 \%$ of the total population. The growth rates of population in border governorates were nearly double those of the total population during most of the study period 1976-2006, except for the last year (2015). The natural increase rate in border governorates $(2.6 \%)$ is slightly higher than the national level $(2.3 \%)$ in 
2015. The border governorates attracted about 247 thousand persons during the period 1996-2006, representing only $5.2 \%$ of those who migrated at the national level. The major cause of population movement to border governorates was looking for (work) (43\%), followed by (attendance) (42\%), where the latter are the followers of the earlier. The urbanization level in border governorates $(68 \%)$ was seemingly higher than that of the national level $(43 \%)$ as of 2006. The total number of labour force in border governorates amounted to 592 thousand in 2015, compared to 479 thousand in 2006, representing about $2 \%$ of total labour force, which is similar to the share of total population. The growth rates of labour force in border governorates are more than double those of the country level, during most of the study period, while they became even lower than the country level in 2015 , as is the case with population. Refined activity rate in border governorates was $65 \%$, similar to that of the national level in 2006. Participation in economic activities was increasing rapidly in border governorates (from $25 \%$ in 1976), compared to the national level (from $45 \%$ in 1976. In border governorates, unemployment rates during the period 1986-2006 (7\%) were lower than those of the national level by about 4 percentage points. By 2015, unemployment rates became closer: being $11.7 \%$ in border governorates and $12.8 \%$ at the national level. The border governorates are currently suffering higher unemployment rates as the rest of the country, and are no longer able to attract more population and provide job opportunities, neither for residents, nor for migrants. In border governorates, more than half the unemployed (57\%) had secondary education and higher (54\% for males and $63 \%$ for females) in 2006, and that relative share declined slightly in 2015 to about 56\% (50\% for males and 52\% for females). The relative share of unemployed with university education and above increased rapidly from $21 \%$ in 2006 to $32 \%$ in 2015 at the national level, and even faster from 14 to $32 \%$ in border governorates: the situation being worse for females than males at the national level in general and in border governorates in particular. For border governorates, the levels, patterns, and trends of educational status of the labour force were more or less similar to those of the national level. Female labour force is better educated than the male counterpart, at both the national and regional levels, and in each border governorate. Employment status of the workers is dominated by "wage workers", at the national level, for border governorates in general, and for each border governorate. The "private sector" continued to be the major job provider, with a rapidly increasing share at both the national level (from 30\% in 1996 to $73 \%$ in 2006), and in border governorates (from $24 \%$ in 1996 to $63 \%$ in 2006). As for female workers, the "government" became the major job provider in border governorates, as $56 \%$ of them belonged to it in 2006, compared to $34 \%$ in 1996. In border governorates, workers with "the white collar occupations" (scientific, professional, technical, administrative, and managerial workers) assumed the first rank, with an increasing trend (being 28\% in 1996 and 31\% 
in 2006). In border governorates, the "community services sector" was the dominant one, with an increasing trend, from $29 \%$ in 1996 to $33 \%$ in 2006. The relative share of "agriculture" was lower and rapidly decreasing in these border and "desert" governorates, from 26\% in 1996 to $15 \%$ in 2006.

\section{4-2 Recommendations:}

According to the results of the analysis concluded above, the researcher can present specific recommendations to the Ministry of Planning in general, and Regional Planning agencies in particular, as follows:

1- It is highly recommended to adopt stable objective criteria (population/area/shape/distances) to establish and cancel governorates, and establishing any new planning/development/administrative regions (regardless of their numbers) has to include complete governorates. It is also strongly suggested to divide border governorates, with large areas and small population, to be allocated to neighboring governorates.

2- Any new foreign, private, and public universities are not to be established in the old Nile Valley and Delta, especially around Greater Cairo. Establishing new universities and faculties, especially those with theoretical specializations, in the established remote border communities.

3- Executing the already available development plans that are prepared for the current border governorates, especially for Sinai and South Egypt.

4- Great interest has to be paid to establish new communities based on reclamation of cultivable lands in current border governorates.

\section{References}

1. Abdel-Hakim, Sobhy (1998) "Reclamation of the Egyptian Deserts: Past Experiences and Future Prospects", Cairo: Supreme Council of Culture, Geography Committee (In Arabic).

2. Abdel-Hamid, Waseem (1994) "Towards a New Population Map for Egypt", Cairo: Institute of Arabic Research and Studies (Special Studies Series, No. 60). (In Arabic).

3. Bharin, Tunku Shamsul (1981) "Review and Evaluation of Attempts to Direct Migrants to Frontier Areas through Land Colonization Themes", in: United Nations (1981) "Population Distribution Policies in Development Planning".

4. Central Agency for Public Mobilization and Statistics (CAPMAS) (1978) "General Census of Population, Housing, and Establishments, 1976", Population Census, Detailed Results, Total Republic, Part One, Ref. No. 93-15111-1978.

5. Central Agency for Public Mobilization and Statistics (CAPMAS) (1988) "General Census of Population, Housing, and Establishments, 1986", Comprehensive Census, Final Results, Vol. 2, Total Republic, ref. No. 863/90/AMT.

6. Central Agency for Public Mobilization and Statistics (CAPMAS) (1998) "General Census of Population, Housing, and Establishments, 1996", Detailed Results of the Population Census, Part One, Total Republic, Ref. No. 11021998-AMT. 
7. Central Agency for Public Mobilization and Statistics (CAPMAS) (2008) "General Census of Population, Housing, and Establishments, 2006", Final Results of the General Census of Population and Housing Conditions, Total Republic. Ref. No. 1102-1103/2008/AMT.

8. Central Agency for Public Mobilization and Statistics (CAPMAS) (2016) "Statistical Yearbook, 2016". Issue No. (107), Ref. No. 71-01111-2016.

9. El-Bakly, Ahmed (2016) "Social and Economic Disparities between the Egyptian Governorates (Is there a balanced regional development?)", Cairo: Institute of National Planning. (In Arabic).

10. El-Zamly, Ahmed (2016) "Population Geography". Cairo: Dar Al-Thaqafa AlArabia. (In Arabic).

11. Hasaneen, Mohammed Ahmed Ali (2009) "Internal Migration in Egypt During the Period 1960-1996: Geographical Study", Unpublished Ph. D. Thesis in Geography, Faculty of Arts, Cairo University. (In Arabic).

12. Institute of National Planning (INP) (2003) "Dividing Egypt Into Planning Regions", Cairo: INP. (Planning and Development Issues Series, No. 162), pp. 128-130. (In Arabic).

13. Institute of National Planning (INP) (2008) "Population Characteristics and Their Reflection on Social Values", Cairo: INP. (Planning and Development Issues Series, No. 210), pp. 73. (In Arabic).

14. Institute of National Planning (INP) (2011) "The Role of New Cities in Geographical Population Redistribution in Egypt", Cairo: INP, (Planning and Development Issues Series, No., 229). (In Arabic).

15. Ministry of Planning (1994) "The National Project of Developing Sinai: Sinai by 2017". Cairo: Ministry of Planning. (In Arabic).

16. Ministry of Planning (1996) "The National Project of Developing South Egypt: South Egypt by 2017". Cairo: Ministry of Planning. (In Arabic).

17. United Nations (1981) "Population Distribution Policies in Development Planning", Papers of the United Nations/UNFP. A Workshop on Population Distribution Policies in Development Planning, Bangkok, 4-13 September 1979. New York: United Nations. (Population Studies, No. 75).

18. United Nations (1984) "Population Distribution, Migration and Development", Proceedings of the Expert Group on Population Distribution, Migration and Development, Hammamet (Tunisia), 21-25 March 1983. New York: United Nations. (International Conference on Population, 1984).

19. Zayyan, Ezzat et al. (1998) "Population, Migration, and Sustainable Development: The Hope of Egypt is to Get Out of the Valley", Cairo: NCPD. (In Arabic).

20. Zayyan, Ezzat (2001) "Migration in the Governorates of South of the Valley", in: Cairo Demographic Center, "The Study of Population Policies in the South of the Valley". (In Arabic).

21. Zayyan, Ezzat (2013) "Trends of Size and Growth of Labour force and Demographic Characteristics", in: Institute of National Planning, "Structural Changes in Labour Force at the Governorate Level in Egypt and Future prospective", (Planning and Development Issues, No. 242). (In Arabic).

22. Zayyan, Ezzat (2016) "Population Redistribution to Achieve Balanced Regional Sustainable Development in Upper Egypt (2006-2027)". In: Bulletin de la Societe de Geographie d'Egypte, Vol. 89, pp. 155-175. 